\title{
Pecularities of the Rural South: The Legacy of Slavery and Cotton Production
}

\section{Joan Weston}
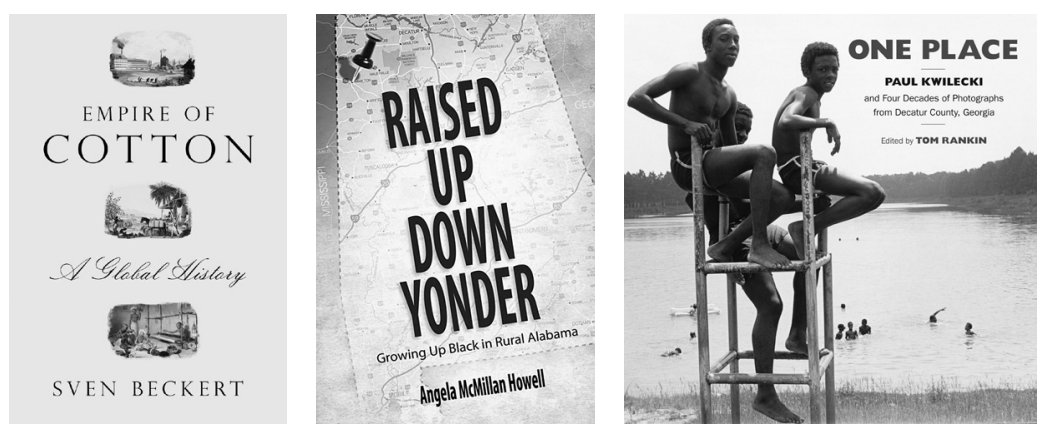

EMPIRE OF COTTON: A Global History. By Sven Beckert. New York: Alfred A. Knopf. 2014.

RAISED UP DOWN YONDER: Growing up Black in Rural Alabama. By Angela McMillan Howell. Jackson: University Press of Mississippi. 2013.

ONE PLACE: Paul Kwilecki and Four Decades of Photographs from Decatur County, Georgia. Edited by Tom Rankin. Chapel Hill: University of North Carolina Press. 2013.

Popular understandings of the rural South have historically been permeated with romanticism. Even texts that are critical in some respect tend to quite easily lapse into a sordid opportunity for unearned redemption. As Margaret 
Mitchell's Gone with the Wind (1929) and Kathryn Stockett's The Help (2009) demonstrate, even the noble quest of Southern white women to break free from the shackles of patriarchy can morph into a thinly veiled homage to slavery and capitalism. In tandem, slavery and capitalism produced the human grist for the nineteenth and twentieth centuries' industrial mills of Europe and North America. Three books, Sven Beckert's Empire of Cotton: A Global History (2014); Angela McMillan Howell's Raised Up Down Yonder: Growing Up Black in Rural Alabama (2013) and Tom Rankin's One Place: Paul Kwilecki and Four Decades of Photographs from Decatur County, Georgia (2013) capture the peculiarities of Southern rurality, and to varying degrees articulate why poverty continues to persist across large swaths of the rural South well into the twentyfirst century.

African Americans in the rural South were essential to the development of capitalism globally. Sven Beckert, the recipient of the Bancroft Award for Empire of Cotton, argues that the expansion of capitalism went hand-in-hand with the enslavement of Africans and cotton production in the South. "So crucial was slave labor," wrote Beckert, "that the Liverpool Chronicle and European Times warned that if slaves ever should be emancipated, cotton cloth prices might double or triple, with devastating consequences for Britain" (110).

Empire of Cotton examines the relationship between cotton production in the rural South and the distribution and manufacturing of cotton globally. Cotton manufacturing is an ancient cultural practice that remained a cottage industry globally for thousands of years before Europeans began cultivating it in the western hemisphere. This subtropical plant flourished in areas where the temperature remained above fifty degrees Fahrenheit and the annual rainfall was at least twenty inches. It grew "[f]rom Gujarat to Sulawesi, along the banks of the Upper Volta to the Rio Grande, from the valleys of Nubia to the plains of Yucatan" (4). People planted cotton along with other crops, nursed it to maturity, and harvested it as they did the crops they ate. For thousands of years, the cotton goods manufactured in the homes of peasants rarely circulated beyond the plant's natural growing zone. According to Beckert, India and China were the centers of the cotton industry while Indian weavers dominated intercontinental trade. Between the sixteenth and eighteenth centuries, the balance of power in the cotton industry shifted. As Beckert notes, "European trade in cotton textiles tied together Asia, the Americas, Africa, and Europe in a complex commercial web" (36). Unable to get a stronghold on the industry through technological innovation, argues Beckert, Europeans used brutality to insert themselves into the worlds of cotton and to dominate global cotton networks. Textiles from Indian weavers paid for millions of enslaved Africans who toiled on Southern cotton plantations. The cotton that enslaved Africans harvested went to factories in Europe and New England where poor white women and children constituted close to 90 percent of the workforce.

Empire of Cotton shows how cotton production and slavery catapulted the rural South onto the center stage of the world economy. No other place 
had elastic supplies of labor, land, and credit. The Mississippi Delta region emerged as "a kind of Saudi Arabia of the early nineteenth century" (113). Beckert states, "as many as sixty thousand Delta slaves produced a staggering 66 million pounds of cotton, nearly ten times as much as was exported from Saint-Domingue to France during the height of its production in the early 1790s" (113).

In the epilogue to Empire of Cotton, Beckert writes:

Here, though, the horrors of slave labor are downplayed or hidden - often intentionally overpowered by the sights of magnificent mansions, beautiful vistas, and well-tended gardens. But none of these historic curiosities can display the greatest invention of the empire of cotton: the globe-spanning network that connected growers, manufacturers, and consumers, a network, that, though radically altered and far from the museums, persists to this day (430).

The infrastructural development in Southern cities and towns were a consequence of the growth and expansion of cotton production in the rural hinterlands of the region. The railroads brought merchants who established stores. Following the Civil War, general stores became the financial artery of the rural South. Through them, Old South elites transformed one of the richest agricultural regions of the United States into the home of the poorest of the nation's poor. Upon regaining ownership of lands confiscated by the United States government, Old South elites - repatriated Confederate plantation owners-reorganized their real estate holdings into smaller tracts and rented them to millions of black and white farmers. While the vast majority of landless farmers were white and worked small landholdings, landless African-American farmers were relegated to landholdings that were similar in size, structure, and organization to the plantations from which enslaved Africans were liberated. Growing exponentially during Reconstruction, general stores sprang up in the center and on the periphery of New South plantation towns and became the sole source of credit for sharecropping consumers, regardless of race.

General stores offered the household and farm supplies that poor rural consumers needed but could not afford without the credit that general store merchants extended to them. Merchants with large plantations monopolized the agricultural credit market. The stock market crash of 1929 may have brought global capitalism to its knees as many Southern towns faded into the sunset along with the general stores in them. In King Cotton and His Retainers: Financing and Marketing the Cotton Crop of the South, 1800-1925 Harold Woodman argues that merchants, who rented to tenants that lived on and farmed their plantations, tended to survive the financial crisis. Those with little land or dependable tenant farmers often perished. Merchants surviving the financial market crisis adapted to the decrease in demand for consumer credit by becom- 
ing more desperate in their business practices. By setting interest rates as high as 35 percent and charging as much as 300 percent above the wholesale price of farm equipment and household supplies, plantation elites turned the country store into a cold hard cog in the regional growth machine producing structural poverty from which the South has yet to recover. ${ }^{1}$

Beckert notes that minimizing labor cost, accessing local infrastructure at no cost, and dominating global markets were economic incentives for reconfiguring "the world's workers and consumers, and the lands and its raw material, in ever new ways" (440). Today the general store Walmart is the nation's largest retailer. According to Beckert, it and other giant retailers control the balance of power between cotton growers, manufacturers, merchants, and the State rather than manufactures, cotton or cloth merchants (432). Walmart's success is due to its ability to organize the production of branded consumer goods and to create channels to offer these goods for purchase all over the world. In the South, it replaced locally owned general stores that once stood at the center of cotton economy. Sam Walton began building his global empire by saturating the United States' cotton producing region of the nineteenth and early twentieth centuries with discount stores. The cotton belt had the highest concentration of enslaved Black people in the United States. Following the Civil War, it had the highest concentration of Black tenant farmers and sharecroppers. AfricanAmerican families rooted in the plantation South used Walmart as an alternative to the local general stores that once service them. ${ }^{2}$ Walmart challenged the locally organized, routine, taken-for-granted everyday business practices in Southern townships and rural communities. By pursuing an aggressive southern expansionist agenda, it increased its profit margin more and faster than any other retailer in the history of the United States. ${ }^{3}$ Unbeknownst to either Sam Walton or Black America, Walmart's march across the rural South allowed African Americans in the region to gain the political traction they needed to further democratic reforms at the local level. But in offering mostly minimum wage and part-time employment, the global retailer prevents the kind of economic development that benefits impoverished families in the rural South. Empire of Cotton opens the door to understanding how global capitalism emerged from and rests fundamentally on the violence and brutality Europeans directed towards geographically displaced Native Americans and Africans enslaved to work without pay and citizenship. Moreover, Beckert opens the door for examining the reconfiguration of global capital such that the retail giant Walmart and the countries of China, India and Vietnam, rather than millions of local merchants in United States, the cotton belt of the American South and the mill towns of Great Britain, are at the center of cotton production, manufacturing and the global economy (440).

Raised Up Down Yonder: Growing Up Black in Rural Alabama focuses on the experiences of poor and working-class African-American youth living in rural West Alabama. ${ }^{4}$ In this ethnographic portrait of rurality, Howell examines the relationship between identity and the structures that reproduce social 
inequality in the rural South. For Howell, identity emerges from social interaction and memory, both collective and individual. The identity of the young people she encounters during her field experience unfolds in the social context of two communities, Hamilton and Carlyle. In both places, the population is split evenly between African Americans and whites, each 50 percent of the total population. Racial segregation remains a common feature of everyday life in Hamilton.

Raised Up Down Yonder is a substantive contribution to the sociological and anthropological scholarship on the rural life of African Americans in the South. Howell provides a description of how family and school, important institutional domains of children's everyday social world, organize and import meaning into young people's everyday experiences. Family, she asserts after a discussion of the spatial arrangements of kinship networks, "remains unparalleled in its influence on young people's lives" (44). Howell pinpoints the spatial organization of households and kinship networks as central to understanding young people's social relations with their families and the broader community. "The spatial environment of Hamilton is the first indication that family is central to young people's experience," she writes. Two residential models are prevalent in Black Hamilton. One has a single residential unit as the command center for a family that gathers there for family functions. According to Howell, an older person with many children maintains the home. Children and grandchildren live in neighboring towns and communities and return to command central on Sundays for dinner. The second residential model evolved from the housing arrangements sharecroppers and white landlords developed during Reconstruction. In this model, several proximal families form a community. Typically, families in this spatial arrangement own small plots and have lived beside each other for multiple generations.

For poor and working-class families, public schools are the nexus between family, the broader community, and the child as an individual. The public school is a mechanism through which poor and working-class parents prepare young people for employment opportunities and, to a lesser extent, for participation in a culture of public responsibility as citizens. The history of schooling for African Americans in Hamilton mirrors the schooling experience of African Americans across the South. Black Hamilton established churches separate from whites. In these sacred spaces, African-American children learned the rudiments of reading, writing, and mathematics. Booker T. Washington, the founder of Tuskegee Institute, developed a model for industrial education and sought to expand the number of institutes in Alabama, each modeled after the flagship in Tuskegee. Julius Rosenwald, the president of Sears, Roebuck and Company from 1908 to 1922, provided matching grants to African-American communities that built schools using Washington's Tuskegee Institute as their model. The Rosenwald schools operated on the principle of self-sacrifice and self-help. For all intents and purposes, these schools were effective in providing an educational foundation under Jim Crow segregation and uplifting the 
community in the face of white supremacy. Howell argues that even though Jay Ellis, Hamilton's K-12 public school, is very far from optimal, its historical significance is critical to the identity of African American youth in Hamilton. Jay Ellis is located on the same land that Hamilton's Black community purchased for the Rosenwald school that served the children before the county's Board of Education built a school for its African-American residents. For Howell, simply attending Jay Ellis makes its students part of the rich heritage of AfricanAmerican schooling in the rural South.

Howell explores Jay Ellis's less than optimal performance in relation to young people's identities by examining the misfortune that often occurs in everyday life. Intentional troublemaking, or "mess," can quickly evolve into conflict, which Howell claims propels the cultural production of misfortune. By sorting through the remains of the day with peers emotionally invested in the outcome of a conflict, young people actively engage in the reproduction of a social structure that devalues the historical significance of Jay Ellis as an institution; the teachers, administrators, and staff who work there, and the students who attend school there. Sorting through the remains also promotes group cohesion. When misfortunate falls, as it did quite often for the poor in Hamilton, "[s]tirring up mess, being messy, and calling people messy all involved other people" (126). Howell goes on to argue that mess prevented young people who experienced misfortunate from retreating into solitude or depression.

The analytical concepts "mess" and "misfortune" are certainly intriguing in and of themselves, especially as they are applied to small-group dynamics. However, Howell fails to anchor these analytical concepts in the scholarship on childhood even though she acknowledges Annette Lareau's Unequal Childhoods: Class, Race and Family Life. Nor does she demonstrate through her ethnography how focusing on African American kids contributes to the scholarship developed within childhood studies. For example, in the last thirty years a robust body of scholarship in history, anthropology, and sociology has emerged on the social construction of childhood and adolescence. ${ }^{5}$ Historiographies exploring identity formation for African-American youth living in rural areas have a long tradition. ${ }^{6}$ Raised Up Down Yonder raises awareness of and interest in this tradition and the social world of black youth living beyond the metropolitan areas of the United States. Her work can help policymakers design policies that address the needs of children in these forgotten areas. By examining the agency of young people in the context of poverty and racism in the rural South, Howell makes visible the rich tradition of African-American self-sacrifice and self-help. Contemporary and historical accounts of local Black self-sacrifice and self-help are largely invisible to young people in Hamilton and the media, who are often misinformed about the centrality of African Americans to the development of global capitalism. Slavery made global capitalism possible. In turned, global capitalists created a model for economic development in the rural South which kept the social and political climate of the region as close as 
legally possible to the social and political climate under slavery. Such a model reproduced poverty rather than upward mobility for the vast majority of landless farmers in the region.

Romanticism does not thrive in the depictions of the rural South collected in Tom Rankin's One Place: Paul Kwilecki and Four Decades of Photographs from Decatur County, Georgia. One Place continues the tradition of documentary photography, which was pioneered by individuals like Jacob Riis, Lewis Hine, Walker Evans, and especially Arthur Rothstein, who took photographs of the descendants of former slaves of the Pettway Plantation in Gee's Bend, Alabama in 1937. The horrors of slave labor have a hard time finding refuge in Kwilecki's Decatur. Kwilecki often brings Black subjects close to the lens. Like his predecessors, his visual representations of poor people show them disheveled yet dignified. In this volume the audience confronts impoverished people struggling with everyday forms of white supremacy, and finding love for themselves and their neighbors through the process. Tenant farmers from Decatur's tobacco fields are fearlessly resolute. The intimacy between Kwilecki and the tobacco workers he photographs appears effortless for both parties. Photographs of stately Victorian homes display white middle-class residents standing on front porches. They appear small, fragile, dazed, confused, and insignificant in comparison to the photographs of poor African Americans on the porches of dilapidated shacks.

In bringing together the photography of Paul Kwilecki (1928-2009), Rankin offers yet another window for thinking about the social and political histories analyzed by Beckert and Howell. Kwilecki, a Jewish hardware merchant taught himself the art of photography and then spent forty years taking pictures of everyday life in his home, Decatur County, Georgia. Rankin, Professor and Director of the Center for Documentary Studies at Duke University, traces Kwilecki's family back to the teenage immigrant Isadore Kwilecki, Paul's grandfather. Isadore came to Decatur in 1865 and worked as a hardware peddler before opening a hardware store in Bainbridge, the county seat of Decatur. Isadore was elected to the city council and a generation later Paul's father served as mayor. Although the Kwelickis were Bainbridge community pillars, Paul had no interest in public service. After graduating from Emory in 1950, he returned to Bainbridge and worked with his father at the hardware store. He married a Methodist, Charlotte Williford, and unceremoniously raised four children. In 1975, four years after his father's death, Paul sold the hardware store and devoted the remainder of his life photographing the ordinary experiences of poor and working-class people in Decatur.

The founders of Decatur named the county after Stephen Decatur, Jr. (1779-1820), a United States naval officer and Commodore notable for his many naval victories in the early nineteenth century. In 1920, 31,785 people lived in the county, the highest population in county's history. Fifty years later, the population declined to 25,203. African Americans are consistently 40 per- 
cent of the population while whites approximate 60 percent. Cotton and tobacco grow in Decatur, but historically peanuts were its largest field crop. A consistent theme throughout One Place is the persistence of poverty in this rural county.

One Place is an important visual history of Decatur County and the rural South more broadly. Photographs in the collection fall into two broad categories: landmarks and work. Landmarks - including a tobacco field, cemetery, bus station, courthouse, supermarket, hardware store, river, hotel, park, factory, warehouse, and several churches - bring specificity to the county's unremarkable scenery. There is Wards Hardware Company, Ms. Bennett's Jewelry Store, the Pilgrim Rest A.M.E Church, the Trailways Bus Station, Decatur County Correctional Institute, and Oak City Cemetery. Workers are an assortment of landless farmers, prisoners, loggers, merchants, carnies, machinists, construction laborers, and maids. These black and white images are a window into the culture and social world of work in Decatur. Kwilecki offers no names for the workers and no personal identification for the subjects in these portraits. The workers themselves stare blankly at the lens, and thus the world from which Kwilecki recoils - middle-class white folk - as if to say, "here I am, love me as I am. It really doesn't matter if you love me. It doesn't matter at all."

The photographs in this volume were taken from the early 1960s to the early 2000s. The organization of this visual history is nonlinear, which is a source of confusion; Rankin places photographs taken in the early 1960s beside those taken in the 1990s. One plausible explanation for the juxtaposition of photographs taken during completely different decades is that Decatur is a place that time has forgotten, and little has changed from the time Kwilecki began photographing the county in the 1960s. Rankin is a minimalist in the sense that he provides an introduction, but precious few words about the photographs assembled in this volume. Like many coffee table books, One Place is an unguided tour of a geographic region and the people who inhabit this region. It just so happens that the region is the rural South and the specific place is Decatur County, Georgia. Regardless of the everyday reality of people living in Decatur, the persistence of poverty and the racial disparity in the criminal justice system and employment is a consistent theme throughout the volume.

Sven Beckert's Empire of Cotton: A Global History, Angela McMillan Howell's Raised Up Down Yonder: Growing Up Black in Rural Alabama, and Tom Rankin's One Place: Paul Kwilecki and Four Decades of Photographs from Decatur County, Georgia capture the unromantic peculiarities of Southern rurality. These books provide news ways of thinking about and understanding economic development policies for the region and ways that current development strategies continue the legacy of development initiated during the expansion of slavery and capitalism in the rural South. Whereas Beckert's Empire of Cotton offers a very convincing argument that African American workers, who went unpaid for their labor even after the abolition of slavery, are at the very core of the processes guiding globalization in the nineteenth and twentieth centuries, Howell's Raised Up Down Yonder and Kwilecki's One Place provide 
a contemporary rendering of the everyday lives of people managing the legacy of globalization, specifically slavery - an aspect of globalization that gets short changed in analyses of the local context. Although cities like Atlanta, Dallas and Miami are in the South, the region remains largely rural. Globalization in the South produced tremendous amounts of wealth in the rural areas for a few individuals and a tremendous amount of poverty for just about everyone else. Because the social and political effects of globalization in the United States are typically associated with cities and industrial development in the North and, after World War II, the West, scholars have been slow to explore the economic, social and political impact of globalization in the South, which began as early as the Transatlantic Slave Trade. New directions in research on globalization and its impacts must include the rural South as a region that is critical to understanding transnational processes and the ways in which the workers, consumers, and the communities in which they labor and make their homes manage the structural forces shaping not just employment opportunities, but the quality of everyday life.

\section{Notes}

1. In addition to producing structural poverty, southern general stores were a mechanism of social control that whites, regardless of class, used to reinforce the ideology of white supremacy and black inferiority. In Gunnar Myrdal, An American Dilemma: The Negro Problem and Modern Democracy (New York: Harper and Brothers Publishers, 1944), Gunnar Myrdal refers to the country store as part of a larger "system" of economic exploitation whose transparency had long been questionable. "There is social significance even in the fact-which every observer will be able to confirm," states Myrdal, "that the system leaves the Negro tenant with the feeling that he has not been treated justly" (247). In Thomas Clarke, Pills, Petticoats and Plows: The Southern Country Store (New York: Bobs-Merrill Company, 1944), historian Thomas Clarke also discusses the limitations of country stores for African Americans. In his analysis of the records of country stores throughout the South, Clarke concludes that Black consumers experienced "a marked degree of whiteness ... There was white meat, white gravy, white bread, and white shortening for the table, white supremacy at the polls and white gloves for the pall bearers at the graveside" states Clarke (160). The brutal murder of Emmett Till in 1955, a fourteen-year-old African-American boy who allegedly flirted with a white woman inside a Mississippi country store, served as a warning to African Americans that the ideology of white supremacy and the social practices constitutive of white male privilege drove the economy and the system of social justice in the United States.

2. Critics of the global retailer often valorize the quaint little country store as the "mom-npop" anchor of Main Street. See John Ehinger, "Wal-Mart Location Gives Way to History," The Huntsville Times (December 7, 2005): 2. In this response to the 2005 closure of Walmart in the West Alabama town of Livingston, The Huntsville Times refers to Walmart's actions as "unsavory." Walmart "drove out its competitors, but felt no real responsibility to continue to serve its customers." Critics like The Huntsville Times demonize the big-box retailer, casting it as an evil empire destroying the local business establishment that had historically served the best interest of the community. However, absent from this critique of globalization run amok is an analysis of the meanings that consumers with a long history of social and political disenfranchisement at the local level attach to the anchors of Main Street and Walmart.

3. See Nelson Lichtenstein, The Retail Revolution: How Wal-Mart Created a Brand New World (New York: Metropolitan Books, 2009).

4. In West Alabama the horrors of slave labor are intentionally hidden but they rear their ugly heads occasionally. Walmart opened in Livingston in 1980. See Brian Landsberg, Free at Last to Vote: The Alabama Origins of the 1965 Voting Rights Act (Lawrence: University Press of Kansas, 2007), where legal scholar Brian Landsberg points out that, Sumter County, whose county seat is Livingston, was an ordinary West Alabama county in the sense that African Americans were the overwhelming majority there. In 1967, approximately two years after Bloody Sunday-the day on which Selma police and Alabama state troopers used batons, attack dogs, and tear gas to stop civil rights activists from marching from Selma to Montgomery-African-American citizens living on Barnes Rogers' plantation, with the assistance of the National Association for the Advancement of 
Colored People (NAACP), went to register to vote at the county courthouse in Livingston. They were sharecroppers farming in retribution, but they were also consumers who had requested from Rogers their rightful share of the USDA cotton price support subsidy and deferred acreage payment.

The Rogers family owned one of the largest plantations in the state of Alabama and, like his father, Barnes was the mayor of Gainesville, a town twenty miles north of Livingston. Rogers gave the families of approximately eighty protesters forty-eight hours to vacate their plantation homes. Evicted families had lived on the north Sumter plantation since Reconstruction. Some moved in with local relatives. Some families migrated to Chicago. The NAACP assisted others in their move to lands owned by Tuskegee University. Adding insult to injury, Rogers leased the plantation land to Hammermill Paper Company. The company planted pine trees up to the doorsteps of those remaining on the plantation in their dilapidated houses, leaving no land open for even a small home garden. Those who remained had to pay two sets of rent, one to Rogers for the house and the other to Hammermill for the land. For more on this see Susan Ashmore, The War on Poverty and the Civil Rights Movement in Alabama, 1964-1972, (Athens: University of Georgia Press, 2008) .

5 . Both childhood and adolescence are contemporary cultural artifacts with historical significance. Social constructivist models analyze childhood and adolescence as human constructs that unfold in real time and places. Critical constructivist scholarship on childhood has its roots in Philippe Aries, Centuries of Childhood: A Social History of Family Life (London: Jonathan Cape, Ltd., 1962) and Norman Denzin, Childhood Socialization: Studies in the Development of Language, Social Behavior, and Identity (San-Francisco, CA: Josey-Bass, 1977). Using paintings, literature, and personal journals as evidence, Aries argues that Europeans had no conception of childhood during the middle ages. According to Aries, children gradually emerged as objects that adults coddled and played with, not necessarily for the psychological or physical well being of the children themselves, but for the fancy of adults amused by the child's charms and antics. Working in the sociological tradition of symbolic interaction, Denzin, like Howell, analyzes the everyday ordinary interactions of children in naturalistic settings. According to Denzin, the self emerges through the acquisition of language and "[in]fants learn language through repeated exposure to conversation" (86). He goes on to assert that childhood is a project in the discovery and creation of the self and that language acquisition is fundamental to these processes. Denzin launched full throttle the critical constructivist critique of developmental psychology. Allison James and Alan Prout furthered this critique in Alan Prout and Allison James, Constructing and Reconstructing Childhood: Contemporary Issues in the Sociological Study of Childhood (London: Falmer Press, 1997). Like Denzin, they also argue that developmental psychology accords priority to biological accounts of children's social status at the expense of children themselves. Richard Archard echoes this critique in Richard Archard, Children:Rights and Childhood (New York: Routledge,1993), where he posits that, from the developmental perspective, "the normal adult, successful maturity, and departures from this ideal can be traced back to false steps in the development itself' (36). Consequently, children are always in a "one-down" position - always structurally inferior to adults, not because of their biological or physical dependency on adults. This perception of inferiority stems from the idea that "the move from each stage of the development to the succeeding one represents a passage from the simpler to the more complex" (33). That is, each stage of the developmental cycle "includes and comprehends the earlier one as a component reintegrated at a higher level, and each succeeding stage is not merely a quantitative increment but a qualitative improvement upon the earlier one" (33). In sum, critical constructivist studies of childhood and adolescence examine the parameters of children's agency and the factors that facilitate and interfere with children's ability to exercise both their civil and human rights.

6. African-American childhood and adolescence are well documented in the historiographies focused on African-American family life. See Wilma King, Stolen Childhood: Slave Youth in the Nineteenth Century (Bloomington: Indiana University Press, 1995) for a close reading of the WPA oral histories of former slaves and the slave narratives published by nineteenth century abolitionists. In her book King argues that childhood was a gift, not from the master, but from the parents of slave children. "If childhood was a special time for enslaved children," she states, "it was because their parents made it so. Black parents stood between [the children] and slaveholders who sought to control them psychologically and to break their will to resist" (1). This argument is echoed in Eugene Genovese, Roll Jordan Roll: The World the Slaves Made (New York: Pantheon, 1974), a historiography examining the organization of everyday social and family life under slavery. This scholarship is largely absent from Howell's analysis of black childhood and adolescence. 